\title{
COPPER OXIDE THIN FILM SYNTHESIS, CHARACTERIZATION AND APPLICATION AS CATHODE IN PHOTOELECTROCATALYTIC CELL FOR METHYL ORANGE DEGRADATION
}

\author{
Gunawan $^{1}$ (1), , Haris A. $^{1}$ and E. Pratista ${ }^{1}$ \\ ${ }^{1}$ Department of Chemistry, Faculty of Sciences and Mathematics, Diponegoro University, Semarang, Indonesia \\ Sciences and Mathematics, Diponegoro University, Semarang, Indonesia
}
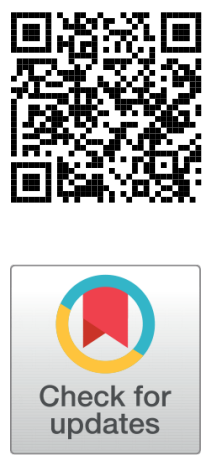

Received 8 June 2021

Accepted 19 June 2021

Published 30 June 2021

Corresponding Author

Gunawan,gunawan@live.undip.ac

id

DOI $10.29121 /$

ijetmr.v8.i6.2021.979

Funding: This research received no specific grant from any funding agency in the public, commercial, or not-for-profit sectors.

Copyright: (C) 2021 The Author(s). This is an open access article distributed under the terms of the Creative Commons Attribution License, which permits unrestricted use, distribution, and reproduction in any medium, provided the original author and source are credited.

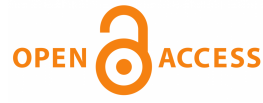

\section{ABSTRACT}

A copper oxide thin film was synthesized through a copper sheet annealing process that was carried out using a gas stove, furnace and $1000 \mathrm{~W}$ tungsten lamp. The product and its photocurrent response were measured using a potentiostat and then characterized by XRD, SEM and EDX. Furthermore, the copper oxide was applied as a photocathode in a photoelectrochemical cell with Platinum (Pt) as the anode for methyl orange degradation, and the thin film annealed at $60 \mathrm{sec}$ produced the highest current density. According to XRD and EDX results, copper oxide structure was dominated by $\mathrm{Cu}_{2} \mathrm{O}$, while SEM showed the presence of a $\mathrm{Cu}_{2} \mathrm{O}$ porous surface. Methyl orange solution degradation also showed the best result for the copper oxide annealed at $60 \mathrm{sec}$ and in all pH variations, while the best degradation was obtained at $\mathrm{pH} 1$.

Keywords: $\mathrm{Cu}_{2} \mathrm{O}$, Photocurrent, Methyl Orange, Degradation

\section{INTRODUCTION}

Contamination by organic pollutants such as dyes, pesticides, and hazardous toxic chemicals is increasing due to the rapid industrial development Ismail et al. (2019); Kasinathan et al. (2016); Mageshwari et al. (2015); Saikia et al. (2015). Organic dyes are one of the main sources of industrial wastewater. These organic dye pollutants are highly toxic and have considerable detrimental effects on human health, the environment and aquatic ecosystems Ismail et al. (2019); Khan et al. (2019); Ramezani et al. (2019); Sharma and Bhattacharya (2017). Amongst various pollutants, methylene blue and methyl orange are the main ones found in wastewater John et al. (2017); Kushwaha et al. (2014); Sahu, Satpati, and Mohapatra (2019). Methyl orange (M0) is an intensely colored toxic compound used in textile industry. It changes from red (at pH 3.1) to orange-yellow (at pH 4.4) John et al. (2017). A number of physical and chemical techniques have been reported for the removal of dye compounds such as adsorption, biodegradation, ozonation, filtration, coagulation and advanced 
oxidation processes such as Fenton's catalytic reaction and Semiconductor photocatalysts Aggarwal (2016). One of the methods for organic dye waste treatments is using photocatalytic process with semiconductors as catalysts and it has received great attention during the last three decades Aggarwal (2016); Kuriakose et al. (2015, 2017); Muthirulan et al. (2017); Sahu, Choudhary, et al. (2019); Sahu et al. (2018); Singh (2015); Singh, Sahu, et al. (2017); Singh, Satpati, and Mohapatra (2017).

Copper oxide as a p-type semiconductor provides promising results for solar energy conversion Abd-Ellah et al. (2016); Sullivan et al. (2016); Wick and Tilley (2015), photoelectrochemical water splitting for hydrogen production Luo et al. (2016); Ma et al. (2015); Wang et al. (2016) and photoelectrocatalytic degradation for hazardous waste treatments Koiki and Arotiba (2020); McMichael et al. (2021); Muthukumaran et al. (2020); Safarvand et al. (2020); Yu et al. (2018). Furthermore, $\mathrm{Cu}_{2} \mathrm{O}$ is cheaply produced, abundant, environmentally friendly, and less toxic compared to other narrow bandgap semiconductors Guzmán et al. (2019); Wick and Tilley (2015).

Semiconductor photocatalysts have been used as a promising method for the removal of organic contaminants because its not only degrade but also cause complete mineralization of pollutants to $\mathrm{H}_{2} \mathrm{O}, \mathrm{CO}_{2}$ and mineral acids. In photoelectrocatalytic dye degradation, $\mathrm{Cu}_{2} \mathrm{O}$ semiconductor when irradiated with photon energy greater than its bandgap, electrons $\left(\mathrm{e}^{-}\right)$are excited from the valence band $\left(\mathrm{V}_{B}\right)$ to the conduction band $\left(\mathrm{C}_{B}\right)$ while creating holes $\left(\mathrm{h}^{+}\right)$in the valence band. A small percentage of electrons and holes migrate to the semiconductor surface and participate in redox reactions to cause dye decomposition that is converted into non-toxic end products Cui et al. (2017) or produce highly reactive superoxide radicals $\left(\mathrm{O}^{2-}\right)$, while holes in $\mathrm{V}_{B}$ react with adsorbed $\mathrm{H}_{2} \mathrm{O}$ or $\mathrm{OH}^{-}$to form highly reactive superoxide radicals in aqueous solutions Ismail et al. (2019); Rameshbabu et al. (2016); Sharma and Bhattacharya (2017).

There are several methods for $\mathrm{Cu}_{2} \mathrm{O}$ thin film synthesis, namely by electrodeposition Mahmood et al. (2017); Vequizo et al. (2015); Yang et al. (2016), spray pyrolysis Bi et al. (2019) and spin coating Eskandari et al. (2014); Oku et al. (2014). But preparation of $\mathrm{Cu}_{2} \mathrm{O}$ from $\mathrm{Cu}$ sheet with heating at ambient atmosphere have not been done before. Therefore, in this research was aimed to utilize the $\mathrm{Cu}_{2} \mathrm{O}$ (Copper Oxide) thin film synthesized from copper sheet through an annealing process (using gas stove, furnace, and 1000W lamp) as a photocatalyst for methyl orange degradation. By using simple techniques compared to the existing ones, easier replication of the copper oxide products on a large scale is expected.

\section{MATERIALS AND METHODS}

\subsection{MATERIALS}

The chemicals and solvents were obtained from a commercial source (Merck) and used without further treatment. Copper sheet $10 \mathrm{~cm}$ x $10 \mathrm{~cm}$ was obtained from 
online shop.

\subsection{SYNTHESIS OF Cu20}

A copper sheet with dimensions of $5 \mathrm{~cm} \times 1 \mathrm{~cm} \times 0.1 \mathrm{~cm}$ was cleaned with acetone. After drying, it was subjected to a variety of heating times. The heaters included an LPG stove, furnace $\left(60{ }^{\circ} \mathrm{C}\right)$ and $1000 \mathrm{~W}$ tungsten lamp. Then, the $\mathrm{Cu}_{2} \mathrm{O}$ thin film formed on the copper sheet was characterized and used for further experiments.

\subsection{TESTING AND CHARACTERIZATION}

Photocurrent response assessed by current-voltage measurement was used to determine the sample's ability as a photocathode. The current-voltage was measured using a Potentiostat and Galvanostat (CS-150) with three electrodes. $\mathrm{Cu}_{2} \mathrm{O}$ sample on the copper sheet was used as working electrode, while platinum and $\mathrm{Ag} / \mathrm{AgCl}$ were used as anode and reference electrodes, respectively. Then the three were immersed in a $0.1 \mathrm{M} \mathrm{Na}_{2} \mathrm{SO}_{4}$ electrolyte solution at $\mathrm{pH}$ 9.0. The measurement was carried out with and without irradiation every 5 sec using a $1.5 \mathrm{AM}$ simulated light at the initial potential of $0.5 \mathrm{~V}$ to the final $-1.0 \mathrm{~V}$ (vs. $\mathrm{Ag} / \mathrm{AgCl}$ ) with a scanning rate of $10 \mathrm{mV} / \mathrm{s}$. The measured potential stated as $\mathrm{Ag} / \mathrm{AgCl}$ was then converted to RHE. Besides, the $\mathrm{Cu}_{2} \mathrm{O}$ sample was characterized by its surface morphology using SEM, and the chemical elemental composition was determined using EDX (Phenom Pro-X desktop SEM with EDX). XRD analysis [PANalytical X Pert3 Powder X-ray diffractometer ( $\mathrm{Cu} \mathrm{K} \alpha$, $\mathrm{Ni}$ filter] was used to identify the crystal structure and grain size.

\subsection{PHOTOELECTROCATALYTIC DEGRADATION OF METHYL ORANGE}

$\mathrm{A} \mathrm{Cu}_{2} \mathrm{O}$ photocathode synthesized at varied heating times and a platinum anode were assembled as shown in Figure 1.

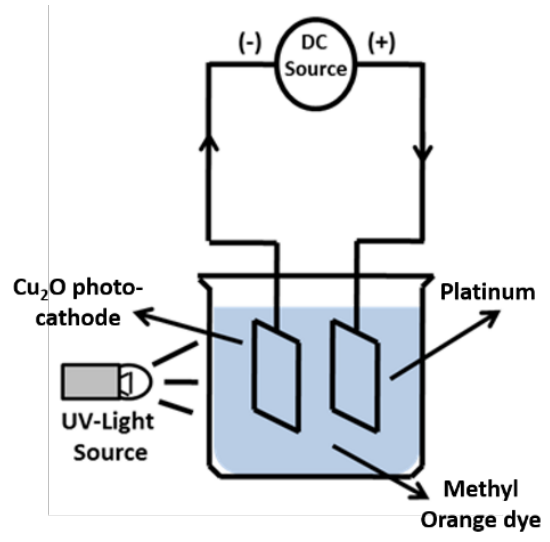

Figure 1 Photoelectrochemical cell apparatus with $\mathrm{Cu}_{2} \mathrm{O}$ photocathode for methyl orange dye degradation 
The photocathode of the $\mathrm{Cu}_{2} \mathrm{O}$ sample and platinum were put in a $50 \mathrm{~mL}$ of $5 \mathrm{mg} / \mathrm{L}$ methyl orange solution with $\mathrm{pH}$ variation of $1,7,8$ and 12 . Then, the degradation process was carried out at $0,15,30,45,60,75$ and 90 min by irradiation using a 20-Watt UV lamp and a bias potential of $0.5 \mathrm{~V}$. The concentration of methyl orange solution before and after degradation were measured using a UV-Vis spectrophotometer (PG Instruments T60 UV-Vis Spectrophotometer).

\section{RESULTS AND DISCUSSIONS}

\subsection{SYNTHESIS OF Cu20}

Copper sheet which was originally metallic red after heating with stove, turned brick red and formed a blackish colored layer. This color change indicated there had been a change in the copper sheet surface area. Oxygen atoms migration from oxygen gas in the interface area caused physical and chemical interactions on the copper sheet surface to ensure a bond occurs between $\mathrm{Cu}$ and $\mathrm{O}$ atoms, hence copper oxide is formed as shown in Equation (1) .

$$
\mathrm{Cu}(s)+\mathrm{O}_{2}(g) \rightarrow 2 \mathrm{Cu}_{2} \mathrm{O}(s)
$$

\subsection{CURRENT-VOLTAGE MEASUREMENT}

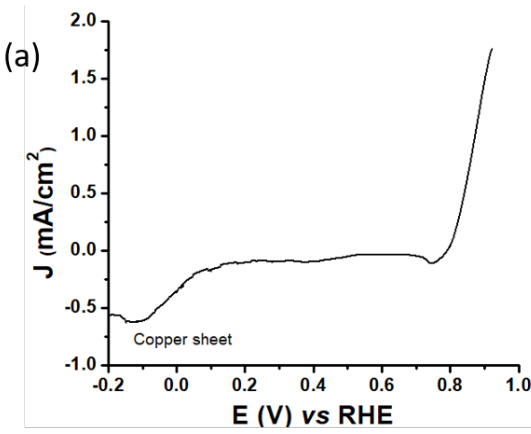

(b)

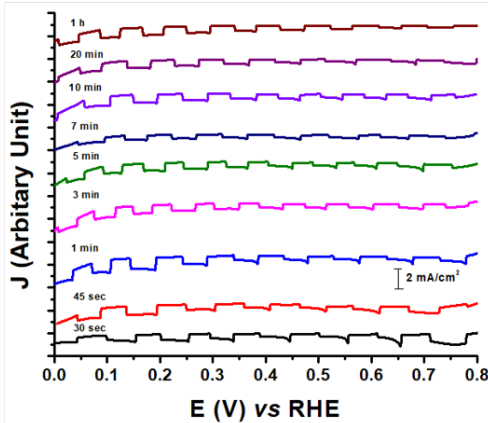

(c)
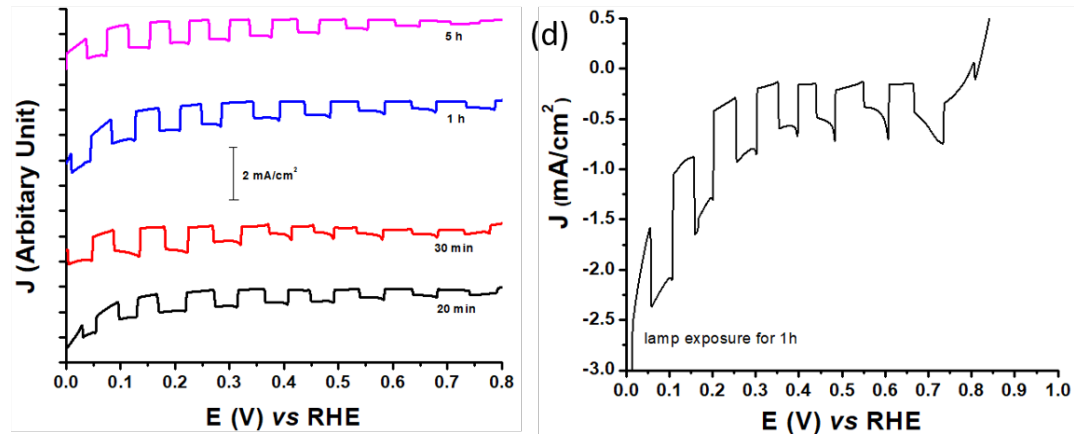

Figure 2 J-V curves on (a) copper sheet, (b) copper sheet after heating with a gas stove, (c) copper sheet after heating by a furnace, and (d) copper sheet after heating with a $1000 \mathrm{~W}$ lamp for certain times. 
Current-Voltage $(\mathrm{J}-\mathrm{V})$ measurement was intended to determine whether the synthesized material provided semiconductive properties by showing the photocurrents. Furthermore, the result for synthesized $\mathrm{Cu}_{2} \mathrm{O}$ on the copper sheet sample before and after heating can be seen in Figure 2 .

According to Figure 2 (a), the copper sheet produced a little current because the sheet used was not $100 \%$ pure as shown in the XRD characterization result. Furthermore, they were heated using a gas stove with time variations as shown in Figure 2 (b). The current density values at $0.185 \mathrm{~V}$ vs RHE of copper plates heated for 30, 40, $60,180,300,420,600,1200$ and 3600 sec were $0.72,0.86,1.15,0.77,0.72,0.53,0.81$, 0.72 and $0.78 \mathrm{~mA} / \mathrm{cm}^{2}$, respectively. Those heated using a furnace with time variations are shown in Figure 2 (c). The current density values at $0.13 \mathrm{~V}$ vs RHE of copper plate heated for $20 \mathrm{~min}, 30 \mathrm{~min}, 1 \mathrm{~h}$ and $5 \mathrm{~h}$ were $0.78,1.14,1.16$ and $1.03 \mathrm{~mA} / \mathrm{cm}^{2}$, respectively. The one heated using a $1000 \mathrm{~W}$ lamp for 1 hour showed a current density value of $0.9 \mathrm{~mA} / \mathrm{cm}^{2}$ at $0.2 \mathrm{~V}$ vs RHE. Therefore, the copper sheet heated with a gas stove produced a better result than the other heaters because besides producing heat, there was also air presence and as oxygen source to oxidize copper. But, when using a furnace, there was no oxygen source in the heating atmosphere.

\subsection{CHARACTERIZATION}

This was carried out using XRD, SEM and EDX, while the samples utilized were copper sheets and $\mathrm{Cu}_{2} \mathrm{O}$ with the highest current density value, namely heating with a gas stove for 1 min. The X-ray diffraction data of the samples are shown in Figure 3.

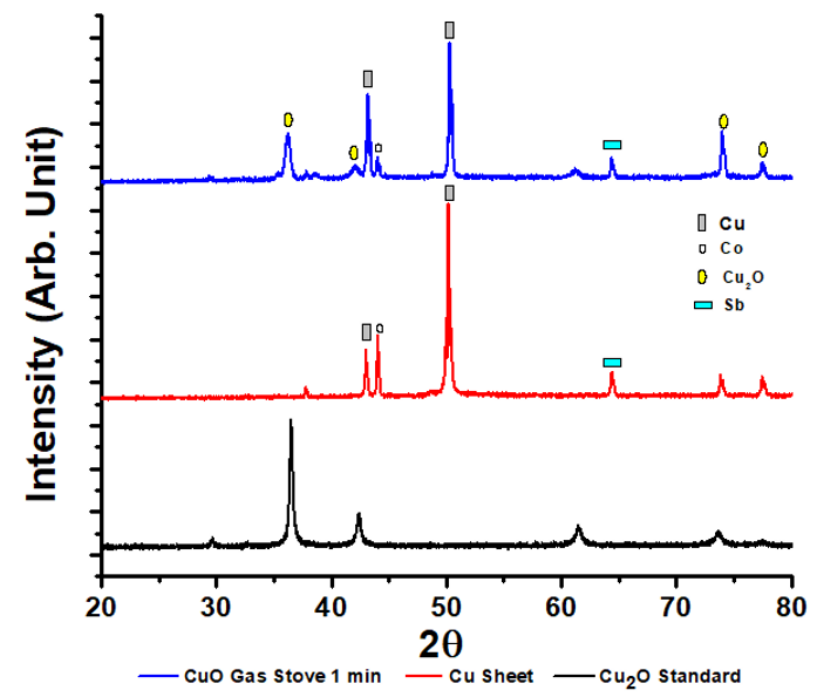

Figure 3 Copper sheet diffractograms before and after heating for $1 \mathrm{~min}$.

The sample XRD spectra peaks were matched with $\mathrm{Cu}_{2} \mathrm{O}$ (RRUFF no R050384) and $\mathrm{Cu}$ (MATCH no entry 96-151-2505) standard data. Copper sheet samples diffraction pattern showed peaks at $2 \theta$ values of 43.013 and $50.153^{\circ}$ which almost coincided 
with the standard peaks at $2 \theta$ of 42.980 and $50.100^{\circ}$. This indicated $\mathrm{Cu}$ sheet used contained $\mathrm{Cu}$ with a crystal size of $52.47 \mathrm{~nm}$. In addition, the $\mathrm{Cu}$ peaks found in the sheet samples at $2 \theta$ of $44.030^{\circ}$ indicated cobalt ( $\mathrm{Co}$ ) presence based on the standard MATCH no entry 96-901-1619. The Co peaks appearance indicated the $\mathrm{Cu}$ sheet used was not $100 \%$ pure. The copper oxide sample heated with the gas stove for $60 \mathrm{sec}$ showed the $\mathrm{Cu}$ peaks were at $2 \theta$ of 43.177 and $50.295^{\circ}$. Besides, some other peaks appeared at the $2 \theta$ of $36.202,42.026 .73 .970$ and $77.451^{\circ}$ which coincide with the standard $\mathrm{Cu}_{2} \mathrm{O}$ RRUFF no R050384 at $2 \theta$ of $36.400,42.200,73.500$ and 77.500 . This showed that by heating treatment, the copper sheet reacted with oxygen from the air, thereby causing copper oxidation to $\mathrm{Cu}_{2} \mathrm{O}$ with a crystal size of $30.78 \mathrm{~nm}$. In addition to the $\mathrm{Cu}$ and $\mathrm{Cu}_{2} \mathrm{O}$ peaks, there was one peak at $2 \theta$ of $44.030^{\circ}$ which indicated cobalt presence based on the standard MATCH no entry 96-901-1619.

SEM-EDX analysis was used to determine the sample surface morphological structure and percentage composition. The samples' SEM analysis results are presented in Figure 4.

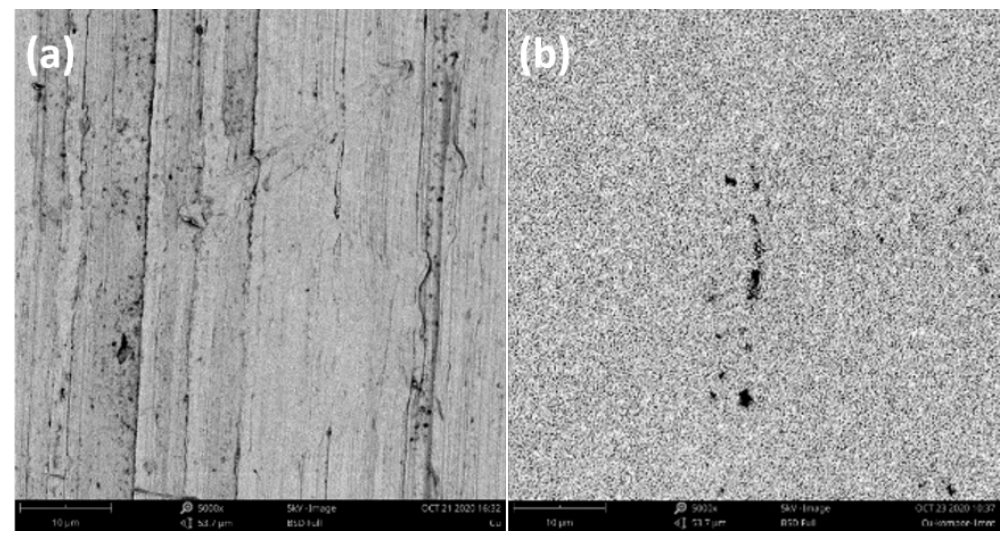

Figure 4 SEM of copper sheet samples (a) before and (b) after heating for 60sec.

According to Figure 4 , the Cu sheet SEM results showed a smooth surface. But on heating for $60 \mathrm{sec}$, the copper oxide sample surface morphology turned rough like a clot due to oxygen influence which indicated copper oxide was formed as $\mathrm{Cu}_{2} \mathrm{O}$. The oxide formation stage began with interface region molecules dynamics because collisions occurred between $\mathrm{Cu}$ and $\mathrm{O}$ atoms. Each element composition present in the sample is presented in Table 1 .

Table 1 EDX analysis for copper sheet before and after heating

\begin{tabular}{|ccc|}
\hline Sample & \multicolumn{2}{c|}{ Elemental composition (\% Mass) } \\
& $\mathrm{Cu}$ & $\mathbf{0}$ \\
\hline Initial copper sheet & 100 & 0 \\
\hline $\begin{array}{c}\text { Copper sheet after heating } 60 \\
\text { sec }\end{array}$ & 87.06 & 12.94 \\
\hline
\end{tabular}


The copper sheet sample EDX analysis results showed only copper element was present, while the sample heated for $60 \mathrm{sec}$ showed there were 0 elements besides the $\mathrm{Cu}$ with a composition of 12.94 and $87.06 \%$ respectively. This showed $\mathrm{Cu}_{2} \mathrm{O}$ was formed on heating for $60 \mathrm{sec}$ as supported by the XRD analysis which proved the $\mathrm{Cu}_{2} \mathrm{O}$ sample on heating for $60 \mathrm{sec}$ has formed $\mathrm{C}_{u 2} \mathrm{O}$ peaks on its diffractogram.

\subsection{METHYL ORANGE (MO) PHOTOELECTROCATALYTIC DEGRADATION USING COPPER OXIDE PHOTOCATHODE}

MO maximum wavelength was obtained by scanning from 200 to $800 \mathrm{~nm}$ of $5 \mathrm{mg} / \mathrm{L}$ MO solution at various $\mathrm{pH}$, and the results are shown in Figure 5 .

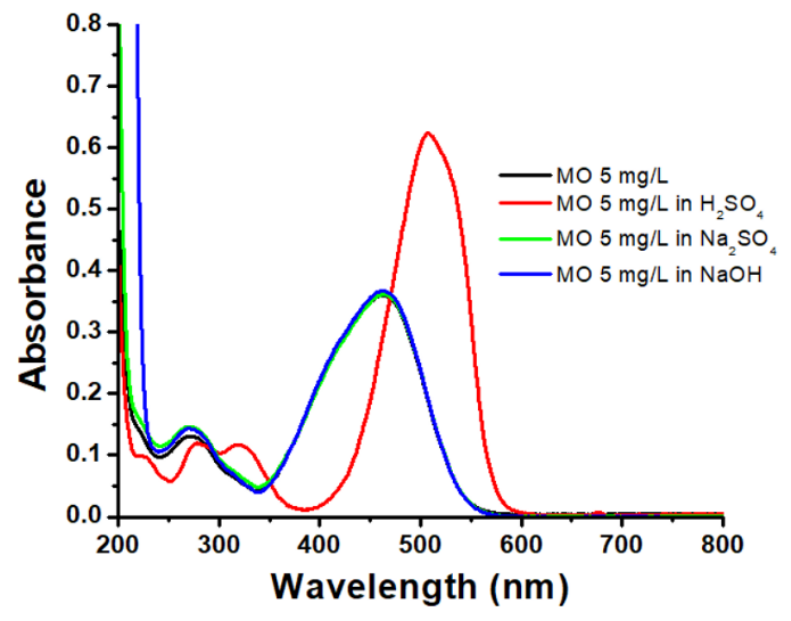

Figure 5 The maximum wavelength of $5 \mathrm{mg} / \mathrm{L} \mathrm{MO}$ at variouspH.

According to Figure 5 , the maximum wavelength of $5 \mathrm{mg} / \mathrm{L} \mathrm{MO}$ was $462 \mathrm{~nm}$ with an absorbance of 0.360 . When adjusting the $\mathrm{pH}$ to be neutral or alkaline using $\mathrm{Na}_{2} \mathrm{SO}_{4}$ or $\mathrm{NaOH}$ solution, there was no maximum wavelength shift, but it was still at 462 $\mathrm{nm}$ with absorbances of 0.361 and 0.368 , respectively. When the $\mathrm{pH}$ was adjusted to be acidic using $\mathrm{H}_{2} \mathrm{SO}_{4}$, there was a color change from bright orange to red, while the maximum wavelength and absorbance also became $508 \mathrm{~nm}$ and 0.623 . Methyl orange changed from an azo structure (orange color) to a quinoid (red) with a $\mathrm{pH}$ value changing from 4.4 to 3.1. Meanwhile, the maximum absorption peak shifted from $463 \mathrm{~nm}$ in almost neutral conditions to $507 \mathrm{~nm}$ at $\mathrm{pH} 2.0$, due to lone pair delocalization in the azo group. The MO structural change at different $\mathrm{pH}$ also caused an increase in the peak intensity at its maximum absorption wavelength Oku et al. (2014). A wavelength increase indicated an increase in delocalization.

The degradation process was carried out using $5 \mathrm{mg} / \mathrm{L}$ MO solution with a varied $\mathrm{pH}$ of 1, 7, 8 and 12, and copper oxide obtained by gas stove heating for $30 \mathrm{sec}, 45$ sec, $1 \mathrm{~min}, 3 \mathrm{~min}$ and $5 \mathrm{~min}$. This treatment aimed to determine heating time and $\mathrm{pH}$ conditions effect on copper oxide ability as a photocathode in methyl orange degradation. The degradation was assessed by measuring the absorbance at 508, 462, 462 
and $462 \mathrm{~nm}$ according to MO maximum wavelength at $\mathrm{pH}$ 1, 7, 8 and 12, respectively.

(a)
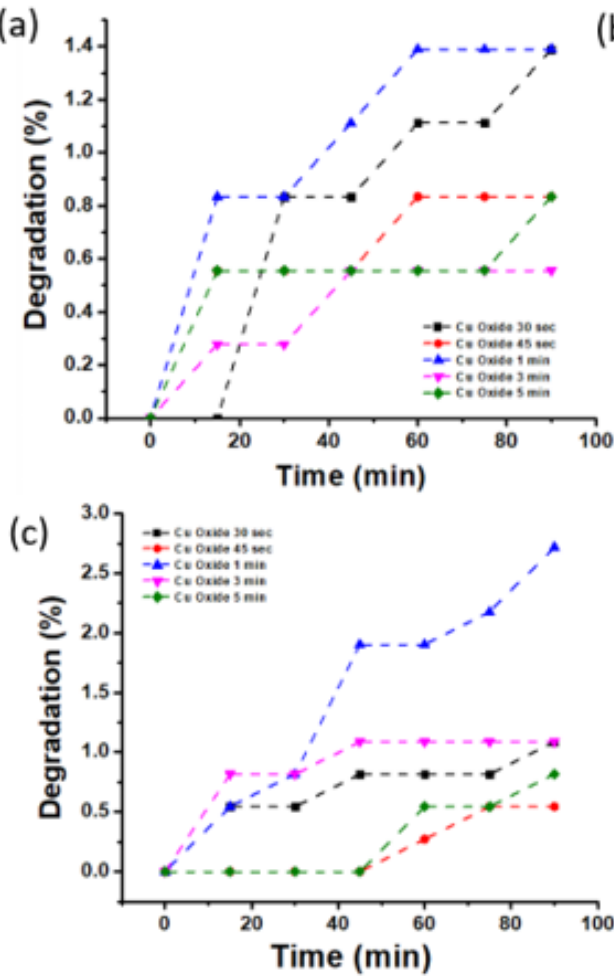

(b)
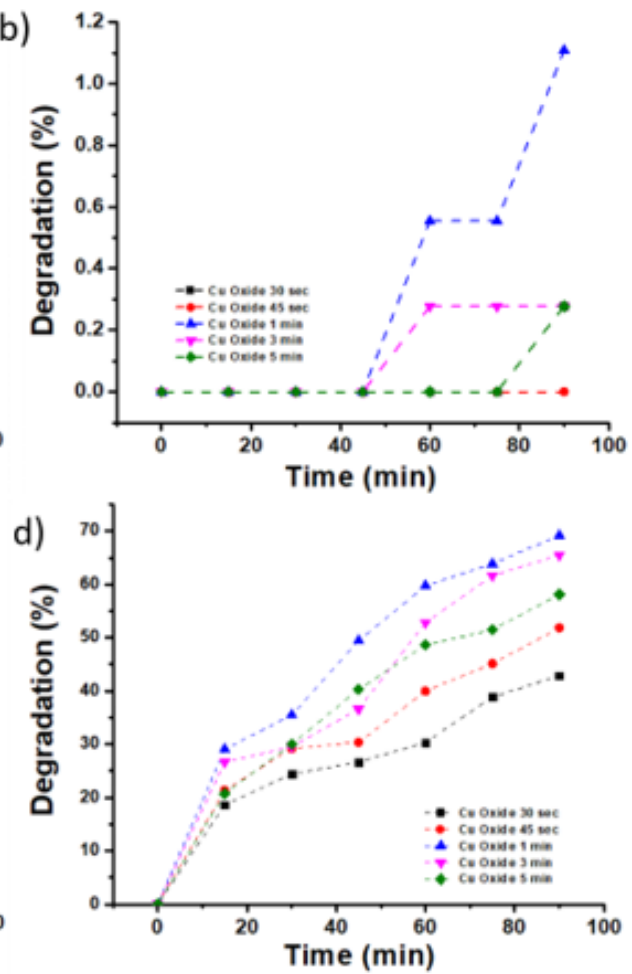

Figure 6 Degradation of $5 \mathrm{mg} / \mathrm{L} \mathrm{MO}$ at $\mathrm{pH}$ (a) 8, (b) 7, (c) 12and (d) 1 treated for ninety minutes with copper oxide synthesized at variedtimes

Based on Figure 6 (a) - (d), the highest reduction occurred in copper oxide samples with a heating time of $60 \mathrm{sec}$ and degradation for $90 \mathrm{~min}$. The highest degradation percentage was $69.18 \%$ at an acidic $\mathrm{pH}$, followed by $2.72 \%$ at an alkaline $\mathrm{pH}$, $1.39 \%$ in the original MO conditions ( $\mathrm{pH} 8$ ) and $1.11 \%$ in $\mathrm{Na}_{2} \mathrm{SO}_{4}$ solution ( $\mathrm{pH} 7$ ). The best degradation at low $\mathrm{pH}$ of MO solution can be explained by the copper oxide zeta potential. The zero-point of the $\mathrm{pH}_{z p c}$ charge for copper oxide is 9 [40] and the $\mathrm{Cu}_{2} \mathrm{O}$ surface is abundant with hydroxyl. Therefore, the surface became positively charged (combined with $\mathrm{H}^{+}$) because the $\mathrm{pH}$ was lower than $\mathrm{pH}_{z p c}$ or negatively charged (when reacting with $\mathrm{OH}^{-}$) because of being greater than $\mathrm{pH}_{z p c}$ [41-43]. The positively charged surface accelerated electrons transfer under acidic conditions, hence facilitating electron-hole pairs' separation. Electrons reacted with the $\mathrm{O}_{2}$ adsorbed on the catalyst surface to produce $\mathrm{H}_{2} \mathrm{O}_{2}$. Both $\mathrm{H}_{2} \mathrm{O}_{2}$ and $\mathrm{h}^{+}$(redox potential of $1.8 \mathrm{~V}$ and $3.0 \mathrm{~V}$ vs. NHE, respectively) are strong oxidants, leading to methyl orange degradation. Although hydroxyl radicals readily form in alkaline media with lots of hydroxyls, $\mathrm{OH}$ oxidant power is lower than that of holes. Hence, a low degradation rate was obtained under alkaline conditions. Another reason for methyl orange degradation under acidic conditions was the structural change when the $\mathrm{pH}$ was below 
3.1. Quinoids have relatively lower bond energies, which are more prone to photodecomposition than azo structures $[42,44]$. The irradiation duration also affected the hydroxyl radicals' amount produced to degrade the dye. The longer the reaction, the more interactions occurred between the photons and photocatalyst. This is consistent with the data that stated 90 min degradation led to the smallest absorbance and largest percentage.

During the process, copper oxide varied in heating time as a photocathode which was illuminated and also experienced holes and electrons generation by light. The electrons reduced water to $\mathrm{H}_{2}$, while the hole migrated to the outer circuit and returned to the solution through the platinum anode and oxidized water to produce $\mathrm{OH}$ - which in turn degraded methyl orange into $\mathrm{H}_{2} \mathrm{O}, \mathrm{CO}_{2}$ and other by-products. Copper oxide ability to vary the heating time was also proven by current density appearance when PEC measurements were carried out. This emerging density of currents showed copper oxide produced electron-hole pairs to reduce water. Based on the measurement results of destruction and current density in Figure 6 and Figure 2 , the copper oxide with $60 \mathrm{sec}$ heating time produced the highest current density value, namely $1.15 \mathrm{~mA} / \mathrm{cm}^{2}$ at $0.185 \mathrm{~V}$ versus RHE and the highest degradation results in the methyl orange solution of all $\mathrm{pH}$ variations. This showed copper oxide with a heating time of $60 \mathrm{sec}$ was the optimum sample for methyl orange degradation. The $\mathrm{Cu}$ sheet by heating on a gas stove for $60 \mathrm{sec}$ in oxygen and heat presence, converted copper into a copper oxide layer, namely $\mathrm{Cu}_{2} \mathrm{O}$ which was formed on top of the $\mathrm{Cu}$ sheet. The increased heating time caused the oxide layer that formed or stuck to the $\mathrm{Cu}$ sheet surface to peel off because of being too thick. Meanwhile, the time was too short, causing the copper oxide layer formation to be not optimal.

\section{CONCLUSION}

Copper oxide with $60 \mathrm{sec}$ heating time produced the highest current density value, namely $1.149 \mathrm{~mA} / \mathrm{cm}^{2}$ at $0.185 \mathrm{~V}$ versus RHE and the highest degradation results in methyl orange solution of all $\mathrm{pH}$ variations. The degradation values for copper oxide heated for 60 sec were $69.18,2.72,1.39$, and $1.11 \%$ at $\mathrm{pH} 1,12,8$, and 7 , respectively. Conclusively, the best degradation of methyl orange was obtained at pH 1.

\section{ACKNOWLEDGEMENTS}

The authors are grateful for the fund provided through the National Budget for the Faculty of Science and Mathematics, UNDIP Fiscal Year 2020 No: 2002/UN7.5.8/PP/2020.

\section{REFERENCES}

Abd-Ellah, M., Thomas, J. P., Zhang, L., \& Tong, K. (2016). Solar Energy Materials \& Solar Cells Enhancement Of Solar Cell Performance Of P-Cu2o/N-Zno-Nanotube And Nanorod Het- 
erojunction Devices. Sol. Energy Mater. Sol. Cells, 152, 87-93.

Aggarwal, S. (2016). Photo Catalytic Degradation Of Methyl Orange By Using Cds Semiconductor Nanoparticles Photo Catalyst. Int. Res. J. Eng. Technol, 3, 2-6.

Bi, J., Wu, S., Xia, H., Li, L., \& Zhang, S. (2019). Synthesis of monodisperse single-crystal Cu2O spheres and their application in generating structural colors. Journal of Materials Chemistry C, 7(15), 4551-4558. Retrieved from https://dx.doi.org/10.1039/c9tc00809h $10.1039 / \mathrm{c} 9 \mathrm{tc} 00809 \mathrm{~h}$

Cui, Z., Yang, H., \& Zhao, X. (2017). Enhanced Photocatalytic Performance Of GC3n4/Bi4ti3o12 Heterojunction Nanocomposites. Mater. Sci. Eng. B Solid-State Mater. Adv. Technol, 229, 160-172.

Eskandari, A., Sangpour, P., \& Vaezi, M. R. (2014). Hydrophilic Cu2O nanostructured thin films prepared by facile spin coating method: Investigation of surface energy and roughness. Materials Chemistry and Physics, 147(3), 1204-1209. Retrieved from https://dx .doi.org/10.1016/j.matchemphys.2014.07.008 10.1016/j.matchemphys.2014.07.008

Guzmán, H., Farkhondehfal, M. A., Tolod, K. R., Hernández, S., \& Russo, N. (2019). Photo/Electrocatalytic Hydrogen Exploitation For Co2 Reduction Toward Solar Fuels Production. Solar Hydrogen Production: Processes, Systems And Technologies, 365-418.

Ismail, M., Akhtar, K., Khan, M. I., Kamal, T., Khan, M. A., Asiri, A. M., Seo, J., \& Khan, S. B. (2019). Pollution, Toxicity and Carcinogenicity of Organic Dyes and their Catalytic Bio-Remediation. Current Pharmaceutical Design, 25(34), 36453663. Retrieved from https://dx.doi.org/10.2174/1381612825666191021142026 $10.2174 / 1381612825666191021142026$

John, N., Tharayil, N. J., \& Somaraj, M. (2017). Photocatalytic degradation of methyl orange using biologically enhanced tin oxide nanoparticles under UV-irradiation. Journal of Materials Science: Materials in Electronics, 28(8), 5860-5865. Retrieved from https:// dx.doi.org/10.1007/s10854-016-6258-7 10.1007/s10854-016-6258-7

Kasinathan, K., Kennedy, J., Elayaperumal, M., Henini, M., \& Malik, M. (2016). Photodegradation of organic pollutants $\mathrm{RhB}$ dye using UV simulated sunlight on ceria based TiO2 nanomaterials for antibacterial applications. Scientific Reports, 6(1), 1-12. Retrieved from https://dx.doi.org/10.1038/srep38064 10.1038/srep38064

Khan, M. S. J., Kamal, T., Ali, F., Asiri, A. M., \& Khan, S. B. (2019). Chitosan-coated polyurethane sponge supported metal nanoparticles for catalytic reduction of organic pollutants. International Journal of Biological Macromolecules, 132, 772-783. Retrieved from https://dx.doi.org/10.1016/j.ijbiomac.2019.03.205 10.1016/j.ijbiomac.2019.03.205

Koiki, B. A., \& Arotiba, O. A. (2020). Cu2O as an emerging semiconductor in photocatalytic and photoelectrocatalytic treatment of water contaminated with organic substances: a review. RSC Advances, 10(60), 36514-36525. Retrieved from https://dx.doi.org/10 .1039/d0ra06858f 10.1039/d0ra06858f

Kuriakose, S., Avasthi, D. K., \& Mohapatra, S. (2015). Effects of swift heavy ion irradiation on structural, optical and photocatalytic properties of $\mathrm{ZnO}-\mathrm{CuO}$ nanocomposites prepared by carbothermal evaporation method. Beilstein Journal of Nanotechnology, 6(1), 928937. Retrieved from https://dx.doi.org/10.3762/bjnano.6.96 10.3762/bjnano.6.96

Kuriakose, S., Sahu, K., Khan, S. A., Tripathi, A., Avasthi, D. K., \& Mohapatra, S. (2017). Facile synthesis of Au-ZnO plasmonic nanohybrids for highly efficient photocatalytic degradation of methylene blue. Optical Materials, 64, 47-52. Retrieved from https://dx.doi.org/ 10.1016/j.optmat.2016.11.035 10.1016/j.optmat.2016.11.035

Kushwaha, A. K., Gupta, N., \& Chattopadhyaya, M. C. (2014). Removal of cationic methylene blue and malachite green dyes from aqueous solution by waste materials of Daucus 
carota. Journal of Saudi Chemical Society, 18(3), 200-207. Retrieved from https://dx .doi.org/10.1016/j.jscs.2011.06.011 10.1016/j.jscs.2011.06.011

Luo, J., Steier, L., Son, M.-K., Schreier, M., Mayer, M. T., \& Grätzel, M. (2016). Cu20 Nanowire Photocathodes for Efficient and Durable Solar Water Splitting. Nano Letters, 16(3), 1848-1857. Retrieved from https://dx.doi.org/10.1021/acs.nanolett.5b04929 10 .1021/acs.nanolett.5b04929

Ma, Q.-B., Hofmann, J. P., Litke, A., \& Hensen, E. J. (2015). Cu2O photoelectrodes for solar water splitting: Tuning photoelectrochemical performance by controlled faceting. Solar Energy Materials and Solar Cells, 141, 178-186. Retrieved from https://dx.doi .org/10.1016/j.solmat.2015.05.025 10.1016/j.solmat.2015.05.025

Mageshwari, K., Nataraj, D., Pal, T., Sathyamoorthy, R., \& Park, J. (2015). Improved photocatalytic activity of $\mathrm{ZnO}$ coupled $\mathrm{CuO}$ nanocomposites synthesized by reflux condensation method. Journal of Alloys and Compounds, 625, 362-370. Retrieved from https:// dx.doi.org/10.1016/j.jallcom.2014.11.109 10.1016/j.jallcom.2014.11.109

Mahmood, A., Tezcan, F., \& Kardaş, G. (2017). Photoelectrochemical characteristics of CuO films with different electrodeposition time. International Journal of Hydrogen Energy, 42(36), 23268-23275. Retrieved from https://dx.doi.org/10.1016/j.ijhydene.2017.06 .003 10.1016/j.ijhydene.2017.06.003

McMichael, S., Fernández-Ibáñez, P., \& Byrne, J. A. (2021). A Review of Photoelectrocatalytic Reactors for Water and Wastewater Treatment (Vol. 13). MDPI AG. Retrieved from https://dx.doi.org/10.3390/w13091198 10.3390/w13091198

Muthirulan, P., Devi, C. N., \& Sundaram, M. M. (2017). Synchronous role of coupled adsorption and photocatalytic degradation on CAC-TiO 2 composite generating excellent mineralization of alizarin cyanine green dye in aqueous solution. Arabian Journal of Chemistry, 10, S1477-S1483. Retrieved from https://dx.doi.org/10.1016/j.arabjc.2013.04 028 10.1016/j.arabjc.2013.04.028

Muthukumaran, M., Gnanamoorthy, G., Prasath, P. V., Abinaya, M., Dhinagaran, G., Sagadevan, S., Mohammad, F., Oh, W. C., \& Venkatachalam, K. (2020). Enhanced photocatalytic activity of Cuprous Oxide nanoparticles for malachite green degradation under the visible light radiation. Materials Research Express, 7(1), 015038-015038. Retrieved from https://dx.doi.org/10.1088/2053-1591/ab63fb 10.1088/2053-1591/ab63fb

Oku, T., Yamada, T., Fujimoto, K., \& Akiyama, T. (2014). Microstructures and Photovoltaic Properties of Zn(Al)O/Cu2O-Based Solar Cells Prepared by Spin-Coating and Electrodeposition (Vol. 4). MDPI AG. Retrieved from https://dx.doi.org/10.3390/coatings4020203 $10.3390 /$ coatings 4020203

Rameshbabu, R., Kumar, N., Karthigeyan, A., \& Neppolian, B. (2016). Visible light photocatalytic activities of $\mathrm{ZnFe} 204$ /ZnO nanoparticles for the degradation of organic pollutants. Materials Chemistry and Physics, 181, 106-115. Retrieved from https://dx.doi .org/10.1016/j.matchemphys.2016.06.040 10.1016/j.matchemphys.2016.06.040

Ramezani, S., Zahedi, P., Bahrami, S.-H., \& Nemati, Y. (2019). Microfluidic Fabrication of Nanoparticles Based on Ethyl Acrylate-Functionalized Chitosan for Adsorption of Methylene Blue from Aqueous Solutions. Journal of Polymers and the Environment, 27(8), 1653-1665. Retrieved from https://dx.doi.org/10.1007/s10924-019-01463-6 10.1007/s10924-019-01463-6

Safarvand, D., Naser, I., Samipourgiri, M., \& Arjmand, M. (2020). Efficient Photoelectrocatalytic Degradation of BTEX Using TiO2/CuO/Cu2O Nanorod-Array Film as the Photoanode and MWCNT/GO/Graphite Felt as the Photocathode. Electrocatalysis, 11(2), 188-202. Retrieved from https://dx.doi.org/10.1007/s12678-019-00576-9 10.1007/ 
s12678-019-00576-9

Sahu, K., Choudhary, S., Khan, S. A., Pandey, A., \& Mohapatra, S. (2019). Thermal evolution of morphological, structural, optical and photocatalytic properties of $\mathrm{CuO}$ thin films. Nano-Structures \& Nano-Objects, 17, 92-102. Retrieved from https://dx.doi.org/ 10.1016/j.nanoso.2018.12.005 10.1016/j.nanoso.2018.12.005

Sahu, K., kuriakose, S., Singh, J., Satpati, B., \& Mohapatra, S. (2018). Facile synthesis of ZnO nanoplates and nanoparticle aggregates for highly efficient photocatalytic degradation of organic dyes. Journal of Physics and Chemistry of Solids, 121, 186-195. Retrieved from https://dx.doi.org/10.1016/j.jpcs.2018.04.023 10.1016/j.jpcs.2018.04.023

Sahu, K., Satpati, B., \& Mohapatra, S. (2019). Facile Synthesis and Phase-Dependent Catalytic Activity of Cabbage-Type Copper Oxide Nanostructures for Highly Efficient Reduction of 4-Nitrophenol. Catalysis Letters, 149(9), 2519-2527. Retrieved from https://dx.doi .org/10.1007/s10562-019-02817-4 10.1007/s10562-019-02817-4

Saikia, L., Bhuyan, D., Saikia, M., Malakar, B., Dutta, D. K., \& Sengupta, P. (2015). Photocatalytic performance of $\mathrm{ZnO}$ nanomaterials for self sensitized degradation of malachite green dye under solar light. Applied Catalysis A: General, 490, 42-49. Retrieved from https:// dx.doi.org/10.1016/j.apcata.2014.10.053 10.1016/j.apcata.2014.10.053

Sharma, S., \& Bhattacharya. (2017). A Drinking Water Contamination And Treatment Techniques. Appl. Water Sci, 7, 1043-1067.

Singh, J. (2015). Thermal Evolution Of Structural, Optical And Photocatalytic Properties Of Tio2 Nanostructures. Adv. Mater. Lett, 6(10), 924-929.

Singh, J., Sahu, K., Pandey, A., Kumar, M., Ghosh, T., Satpati, B., Som, T., Varma, S., Avasthi, D. K., \& Mohapatra, S. (2017). Atom beam sputtered Ag-TiO 2 plasmonic nanocomposite thin films for photocatalytic applications. Applied Surface Science, 411, 347-354. Retrieved from https://dx.doi.org/10.1016/j.apsusc.2017.03.152 10.1016/j.apsusc .2017.03.152

Singh, J., Satpati, B., \& Mohapatra, S. (2017). Structural, Optical and Plasmonic Properties of Ag-TiO2 Hybrid Plasmonic Nanostructures with Enhanced Photocatalytic Activity. Plasmonics, 12(3), 877-888. Retrieved from https://dx.doi.org/10.1007/s11468-016 -0339-6 10.1007/s11468-016-0339-6

Sullivan, I., Zoellner, B., \& Maggard, P. A. (2016). Copper(I)-Based p-Type Oxides for Photoelectrochemical and Photovoltaic Solar Energy Conversion. Chemistry of Materials, 28(17), 5999-6016. Retrieved from https://dx.doi.org/10.1021/acs.chemmater .6b00926 10.1021/acs.chemmater.6b00926

Vequizo, J. J. M., Zhang, C., \& Ichimura, M. (2015). Fabrication of Cu20/Fe-O heterojunction solar cells by electrodeposition. Thin Solid Films, 597, 83-87. Retrieved from https:// dx.doi.org/10.1016/j.tsf.2015.11.034 10.1016/j.tsf.2015.11.034

Wang, W., Zhang, W., Meng, S., Jia, L., Tan, M., Hao, C., Liang, Y., Wang, J., \& Zou, B. (2016). Enhanced photoelectrochemical water splitting and photocatalytic water oxidation of Cu20 nanocube-loaded BiVO4 nanocrystal heterostructures. Electronic Materials Letters, 12(6), 753-760. Retrieved from https://dx.doi.org/10.1007/s13391-016-6224-9 10.1007/s13391-016-6224-9

Wick, R., \& Tilley, S. D. (2015). Photovoltaic and Photoelectrochemical Solar Energy Conversion with Cu20. The Journal of Physical Chemistry C, 119(47), 26243-26257. Retrieved from https://dx.doi.org/10.1021/acs.jpcc.5b08397 10.1021/acs.jpcc.5b08397

Yang, Y., Xu, D., Wu, Q., \& Diao, P. (2016). Cu20/CuO Bilayered Composite as a HighEfficiency Photocathode for Photoelectrochemical Hydrogen Evolution Reaction. Scientific Reports, 6(1), 1-13. Retrieved from https://dx.doi.org/10.1038/srep35158 10 
$.1038 / \operatorname{srep} 35158$

Yu, C., Shu, Y., Zhou, X., Ren, Y., \& Liu, Z. (2018). Multi-Branched Cu2o Nanowires For Photocatalytic Degradation Of Methyl Orange. Mater. Res. Express, 5, 35046-35046. 